\section{Metabolism of L-Leucine-U- ${ }^{14} \mathrm{C}$ in Young Rats Fed Excess Glycine Diets}

\author{
Hisanao TaKeuchi, Nobuo TAdauchi \\ and Keiichiro Muramatsu
}

\author{
Department of Agricultural Chemistry, Faculty of \\ Agriculture, Shizuoka University, \\ Oya, Shizuoka 422
}

Received April 7, 1975

As reported previously, ${ }^{1 \prime}$ while the growth-depressive effect of excess glycine was prevented by the supplementation of L-arginine and L-methionine, the degradation of glycine-U- ${ }^{14} \mathrm{C}$ into the expired $\mathrm{CO}_{2}$ was not accelerated by the supplementation of both amino acids. However, the incorporation of the isotope into lipids of the liver and carcass was found to increase in the rats fed the excess glycine diet containing both amino acids. ${ }^{2)}$ The lipid synthesis utilizing excess glycine may be accelerated by adding $\mathrm{L}$-arginine and $\mathrm{L}$-methionine to the $10 \%$ casein diet containing excess glycine. In the experiments reported in the present paper, the metabolic fate of L-leucine-U- ${ }^{14} \mathrm{C}$ was studied in rats fed the excess glycine diets with or without L-arginine and L-methionine.

Male weanling rats of the Donryu strain weighing 70 to $75 \mathrm{~g}$ fed a stock diet ( $25 \%$ casein) for 3 to 4 days were divided into three groups of 4 to 5 rats. Each was fed one of the following diets: $10 \%$ casein (10C), $10 \%$ casein diet containing $7 \%$ glycine $(10 \mathrm{C} 7 \mathrm{G})$, and $10 \mathrm{C} 7 \mathrm{G}$ supplemented with $1.4 \% \mathrm{~L}$-arginine $\cdot \mathrm{HCl}$ and $0.9 \%$ L-methionine (10C7GArgMet). The composition of the $10 \mathrm{C}$ diet in detail and the amounts of supplemented amino acids were as described in the previous reports. $^{1,2}$ Animals were fed ad libitum for 14 days and then fasted for $12 \mathrm{hr}$ before the last feeding. Fasted rats were force-fed $10 \mathrm{ml}$ of the diet suspension containing $4 \mu \mathrm{Ci}$ of $\mathrm{L}$-leucine-U-14 $\mathrm{C}$ per $100 \mathrm{~g}$ of body weight. Other treatments of animals were as described previously, ${ }^{21}$ except that the expired $\mathrm{CO}_{2}$ was collected at 2- to 4-hr of intervals for $12 \mathrm{hr}$ after the last feeding. The radioactivities ${ }^{2}$ in the expired $\mathrm{CO}_{2}$, trichloroacetic acid (TCA) soluble fraction, protein, glycogen, lipids and urine, and the concentrations ${ }^{3,4)}$ of free amino acids in the blood plasma, liver and urine were measured by the previously described methods.

The body weight gain and food intake of the $10 \mathrm{C} 7 \mathrm{G}$ group $(19.7 \pm 2.4 \mathrm{~g})$ were much smaller than those of the $10 \mathrm{C}(57.5 \pm 2.3 \mathrm{~g})$ and the $10 \mathrm{C} 7 \mathrm{GArgMet}(66.0 \pm$ $9.9 \mathrm{~g})$ groups. ${ }^{1 \sim 3)}$ The recovery of ${ }^{14} \mathrm{C}$-radioactivity

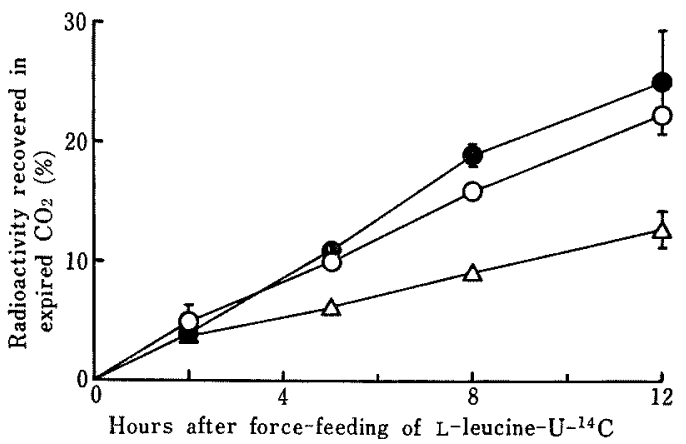

FIG. 1. Changes in Radioactivity Recovered in Expired $\mathrm{CO}_{2}$ after an Oral Loading Dose of L-Leucine$\mathrm{U}-{ }^{14} \mathrm{C}$.

After rats were fed ad libitum the $10 \%$ casein diets containing $7 \%$ glycine with or without L-arginine and L-methionine for 14 days, they were fasted for $12 \mathrm{hr}$ and then force-fed $10 \mathrm{ml}$ of the diet suspensions containing $4 \mu \mathrm{Ci}$ of $\mathrm{L}$-leucine-U-14 $\mathrm{C}$ per $100 \mathrm{~g}$ body weight. $0,10 \%$ casein; $\bullet,+7 \%$ Gly; $\triangle,+7 \%$ Gly $+1.4 \%$ L-Arg $\cdot \mathrm{HCl}+0.9 \%$ L-Met.

L-Arg. $\mathrm{HCl}(1.4 \%)$ and L-Met $(0.9 \%)$ equal the contents of $\mathrm{L}$-arginine and L-methionine in a $30 \%$ casein diet. Vertical lines indicate the standard errors of means.

in the expired $\mathrm{CO}_{2}$ of rats fed the 10C7GArgMet diet was much lower than that of the other groups (Fig. 1). The similar result was obtained in the previous experiment ${ }^{21}$ using glycine-U- ${ }^{14} \mathrm{C}$ in place of L-leucine-U${ }^{14} \mathrm{C}$, though the degree of the decrease of the expiratory ${ }^{14} \mathrm{CO}_{2}$ in the $10 \mathrm{C} 7 \mathrm{GArgMet}$ group force-fed glycine- ${ }^{14} \mathrm{C}$ was smaller than that in the same group force-fed $\mathbf{L}$ leucine- ${ }^{11} \mathrm{C}$. The reduced recovery of radioactivity in the expired $\mathrm{CO}_{2}$ in the previous experiment ${ }^{21}$ using glycine- ${ }^{14} \mathrm{C}$ compared to that in the present experiment using L-leucine-14 $\mathrm{C}$ might be due to the dilution of glycine-14 $\mathrm{C}$ by body free glycine, the concentration of which is higher than that of leucine. The ${ }^{14} \mathrm{C}$-radioactivity in the expired $\mathrm{CO}_{2}$ of the $10 \mathrm{C} 7 \mathrm{GArgMet}$ group force-fed L-leucine- ${ }^{14} \mathrm{C}$ was in an inverse proportion to that in the protein of plasma, liver and muscle (Table I), though that of the same group force-fed glycine- ${ }^{14} \mathrm{C}$ was inversely proportional to the incorporation of the isotope into liver and carcass lipids as reported previously. ${ }^{2)}$ The supplementation of $\mathbf{L}$-arginine and $\mathrm{L}$ methionine may accelerate the utilization of amino acids. The recovery of ${ }^{14} \mathrm{C}$-radioactivity in the TCA soluble fraction of plasma, liver and muscle, in the glycogen of liver and muscle, in lipids of the liver and in the urine were less than $2 \%$ in all groups, and were not so much different among each group (Table I). Six to nine percent of recoveries of radioactivity were observed in lipids of the carcass of each group (Table I). The recovery in the TCA soluble fraction of plasma and 


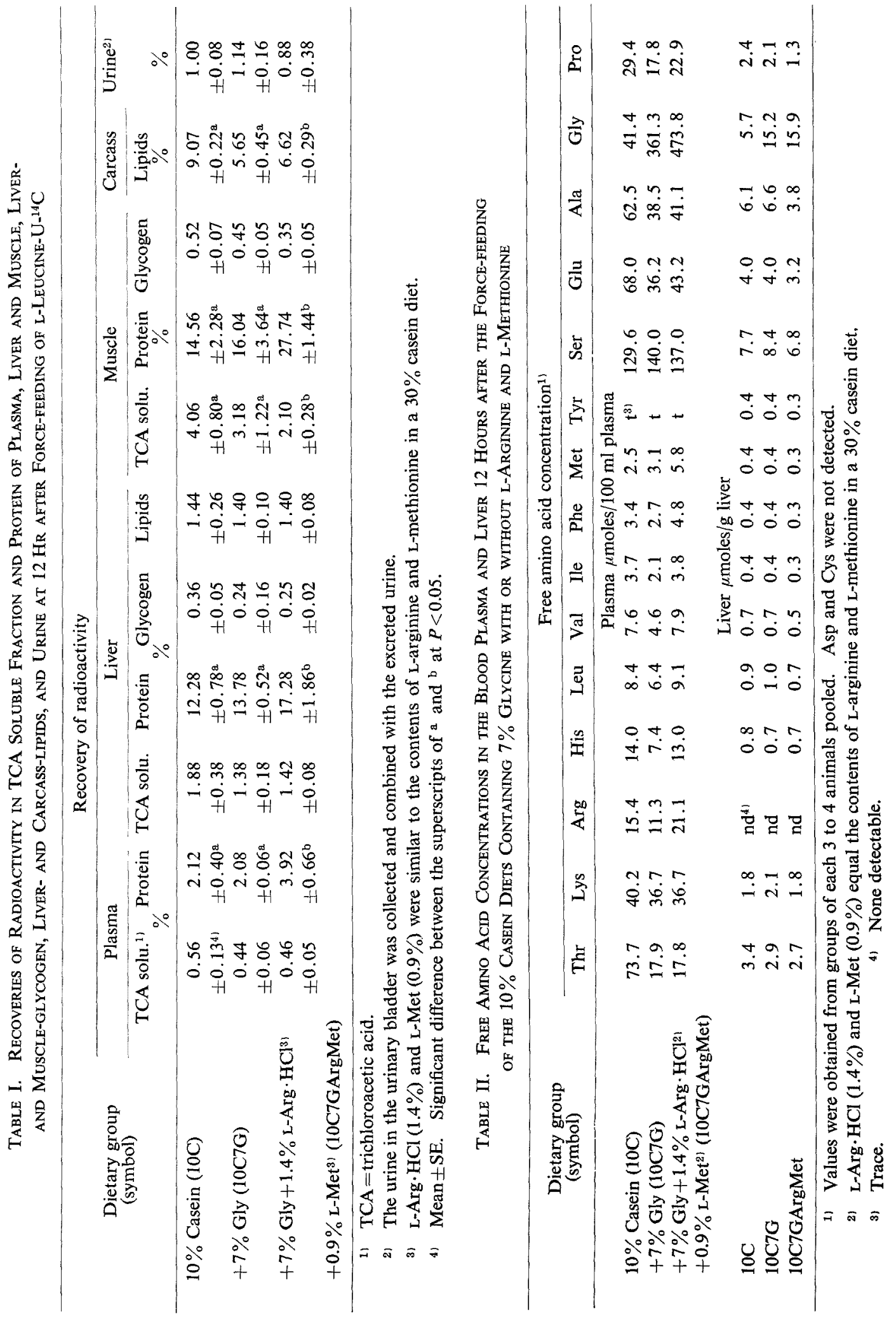


tissues was extremely lower than that found in the previous experiment ${ }^{2 /}$ using glycine ${ }^{14} \mathrm{C}$. That the dilution of L-leucine-14 $\mathrm{C}$ by body free leucine might be smaller than that of glycine-14 $\mathrm{C}$ could explain this difference, because the concentration of glycine was higher than that of leucine in the plasma and liver (Table III). The concentrations of free amino acids in the plasma and the liver in Table $\Pi$ were generally similar to those of the previous reports. ${ }^{3,4)}$ The decrease of plasma threonine concentration in both of the excess glycine groups may suggest that the degradation of threonine is accelerated by the enhancernent of serine dehydratase activity, because the enzyme activity was increased by the supplementation of L-arginine and L-methionine to the $10 \%$ casein diet with or without glycine. ${ }^{3,4}$ )

\section{REFERENCES}

1) H. Takeuchi, T. Tanaka and K. Muramatsu, Agr. Biol. Chem., 33, 1161 (1969).

2) H. Takeuchi, T. Wakatsuki and K. Muramatsu, ibid., 39, 939 (1975).

3) H. Takeuchi, M. Koike and K. Muramatsu, ibid,, 37, 2609 (1973).

4) 'H. Takeuchi, S. Sato, Y. Kishi and K. Muramatsu, ibid., 38, 1325 (1974). 